$1988,37,2$

\title{
STROBOSCOPIC SAMPLING INTO GAS CHROMATOGRAPH: THE POSSIBILITY OF STUDYING NONSTATIONARY GAS FLOWS
}

\author{
(Presented by 0. Lille)
}

\section{Introduction}

Nonstationary gas flows are those whose composition changes with time. These are, e.g., the composition of environmental gas flows or headspace components of a chemical reaction. In its nature a chromatographic analysis is discrete, allowing the analysis of nonstationary processes whose composition changes at a rate comparable to that of separation of evolved products in the chromatographic column. Usually this analysis is performed by taking samples from nonstationary flows at equal intervals $\Delta t$, i. e. the time necessary for the separation of components in the column. We call this method an equi-interval sampling. The time interval we call the time resolution of the process. The continuous functions of component concentrations of time are regenerated from a set of peak area measurements. For the regeneration of the continuous concentration the interval, $\Delta t$, must be chosen according to the sampling theorem requirements (see e. g. [ [']).

What are the $\Delta t$ values that can be used? Taking, for example, the first-order chemical reaction $A \rightarrow B$, the amount of reagent $A$ decreases according to the exponential function $\exp (-k t)$ where $t$ is time and $k$ is the rate constant. Let us assume that the detector in use has a dynamic range of $10^{R}$, where $R$ is a constant. Although for the determination of parameters of the exponential function only two measurements are required, to achieve higher reliability, say, the $n+1$ concentration values are measured from the stream. It means that $\exp (-n \Delta t k)=10^{-R}$ and half of the reactant is consumed during the time $t_{1 / 2}$ which is equal to

$$
t_{1 / 2}=\frac{\ln 2}{\ln 10} \frac{n}{R} \Delta t
$$

Taking $n=4$ and $R=4$ (a realistic value for common GC measurements) we obtain $t_{1 / 2}=0.3 \Delta t$.

Although high-speed chromatography using short capillary columns allows separation within seconds, common chromatographic separation is in general performed within minutes. It follows from Eq. (1) that the duration of the process that can be studied by equi-interval sampling falls into the same range, i. e. it is relatively slow.

\section{Stroboscopic sampling}

If the process is reproducible, then it can be initiated several times and for each process reproduction a sample of a small slice of the process can be taken. By scanning the time between the initial and sample taking 
moments, the composition of the nonstationary flow can be measured with time resolution that is determined by the functioning speed of contemporary sampling devices. The time resolution is irrelevant to the time of the separation of components in the column and may have whatever value.

Contemporary air-driven mechanical valves have commonly a switching time of about $0.1 \mathrm{sec}$ and according to the above discussion, it is possible to measure a process that lasts about half a second. By using fluidic switches for sample introduction, it is possible to use $\Delta t=10 \mathrm{msec}$ and measure the process lasting for $0.05 \mathrm{sec}$. So, the chromatographic method appears to be suitable for the analysis of several interesting chemical reactions (e.g. ignition or catalytic oxidation).

For a successful application of the stroboscopic sampling the following conditions must be held:

1) the process must be reproducible with great precision;

2) the time between the process initiation and sampling must be known and reproducible very exactly. These requirements, however, can be easily fulfilled by using microcomputer-based timing devices that can generate time intervals with a standard deviation better than $\mu$ sec;

3 ) computerised experiment control is necessary. Although in literature approaches can be found where the kinetic measurements by GC can be called "stroboscopic", e. g. in [ $\left.{ }^{2}\right]$, the human operator's capability of exactly reproducing time intervals is limited if $\Delta t \leqslant 1 \mathrm{sec}$. Moreover, the necessity to follow sophisticated timing sequences, as required in stroboscopic sampling, becomes tedious to whatever skilful operator. On the other hand, a microcomputer control of this experiment is trivial for any reasonable $\Delta t$ value.

\section{Example: stroboscopic sampling of dehydration reaction products}

3.1. Equipment. For the practical realization of an idea of stroboscopic sampling an apparatus was constructed consisting of two chromatographs and two mechanical valves. The equipment was controlled by the computer.

A basic scheme of the equipment is presented in Fig. 1. The reagent source is in a heated stainless steel vessel. The reagent vapour is carried out from the vessel to the atmosphere by the inert carrier gas that flows through the reagent loop of a Valco valve (C6TX). By a command from the Apple II microcomputer the valve injects a reagent to the solid catalyst column that is placed in the oven of the first chromatograph (VorruKrom). The second inert carrier gas stream carries the reagent pulse through the catalyst column where the reagent pulse overcomes the reaction. The reaction products are carried through the thermal conductivity detector and the sampling loop out to the atmosphere. By a command from the Apple II computer the sampling valve injects the heart cut of the reaction products band to the analytical column located in the second chromatograph (LHM-60). After the separation in the analytical column the reaction products are detected by the flame ionization detector.

Both the detector signals are converted to digital form and stored in Apple II memory for future data processing.

3.2. Model reaction and chromatographic conditions. The reagent was $n$-butanol. The catalyst was phosphoric acid on teflon beads. The length of the catalytic column was $2 \mathrm{~cm}$ and the diameter $3 \mathrm{~mm}$. In the dehydration reaction, alcohol reacts to a number of olefins the unresolved band of which is separated from the nonreacted alcohol band by a $1 \mathrm{~m} \times 3 \mathrm{~mm}$ 


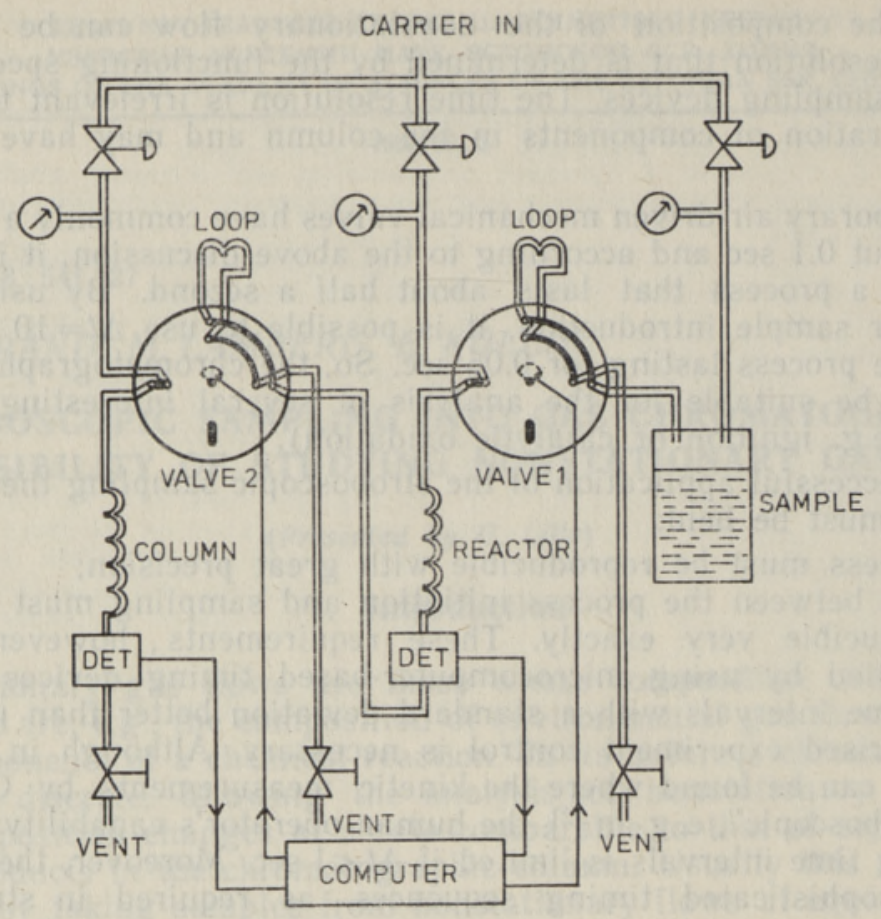

Fig. 1. Experimental setup.
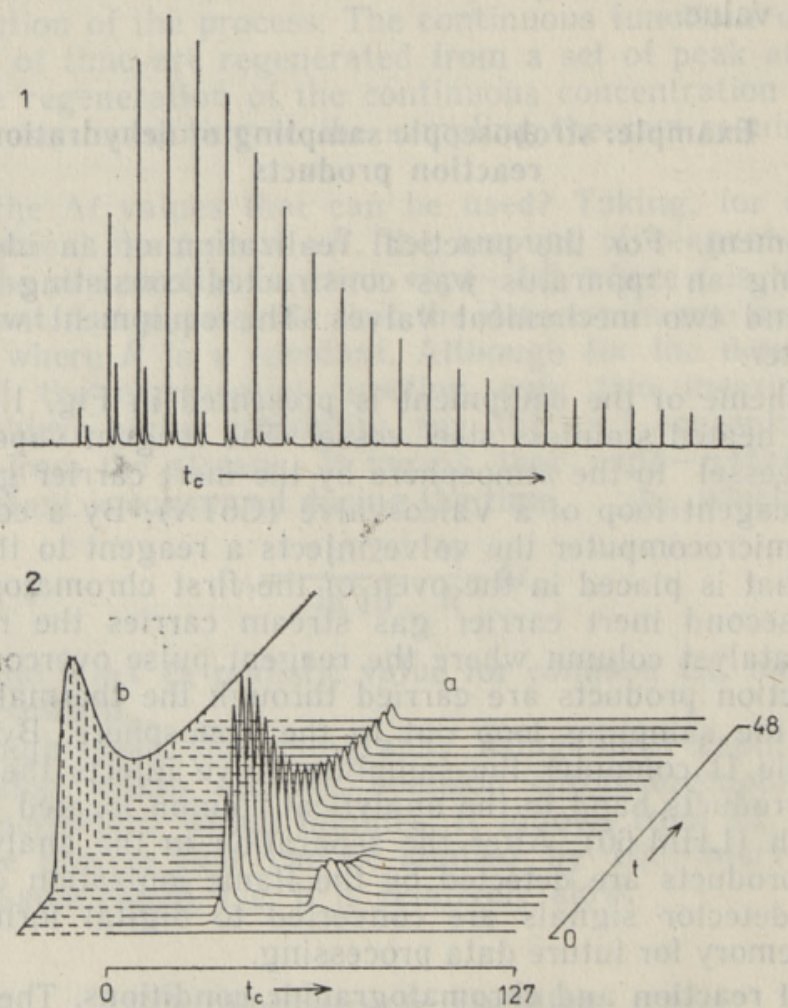

Fig. 2, 1 - time resolved chromatograms from the analytical column, $2 a-$ isometric projection of chromatograms of Fig. 2. $1,2 b-$ TCD signal averaged over all single records, dotted lines show the "cut" moments $\left(t-\right.$ reaction run time, $t_{c}-$ chromatogram run time (in seconds)), 
column filled with Apiezon on Inerton AW ( $60-80$ mesh). The column temperature was $90^{\circ} \mathrm{C}$.

According to the model in $\left[{ }^{3}\right]$ the products amount at the end of the catalyst column changes as a difference of two exponent functions. The rate constant of one exponent is the rate constant of the dehydration reaction and the rate constant of the second exponential describes the mass transport phenomena in the catalytic column.

3.3. Results and discussion. During the experiment the catalyst temperature was varied from 120 to $190^{\circ} \mathrm{C}$. A typical experimental output signal is presented in Fig. 2. (catalyst temperature $150^{\circ} \mathrm{C}$ ). The output of experiment is a set of chromatograms from the analytical column obtained by heart cutting the catalytic column output products at different time moments (from the beginning of the reaction up to the time moment when the TCD signal becomes negligible). The lowest $\Delta t$ value was $1 \mathrm{sec}$.

The rate constants were computed by the least squares fitting of the product peak areas to the difference of two exponents. The standard deviation of the rate constant is $5 \%$ of the mean rate constant value. The logarithm of the rate constant as a function of the reciprocal absolute temperature is presented in Fig. 3. Also in this figure measurements from the experiments performed within the temperature interval 100$140^{\circ} \mathrm{C}$ are presented in [4]. These experiments are performed in the Laboratory of Gas Chromatography of Leningrad State University (LSU). Both lines in Fig. 3 can be described by the following functions:

the present work: $\ln k=30.3-94.2 \cdot 10^{3} / R T$

LSU measurements: $\ln k=29.8-95.6 \cdot 10^{3} / R T$

$(c c=0.992)$, $(c c=0.982)$.

Here $c c$ means correlation coefficient, $R=8.31 \mathrm{KJ} / \mathrm{mol}$.deg and $T$ is absolute temperature.

The agreement between two experiments is remarkable (parameters differ by less than $1.5 \%$ ) despite the differences in the experiment set-up.

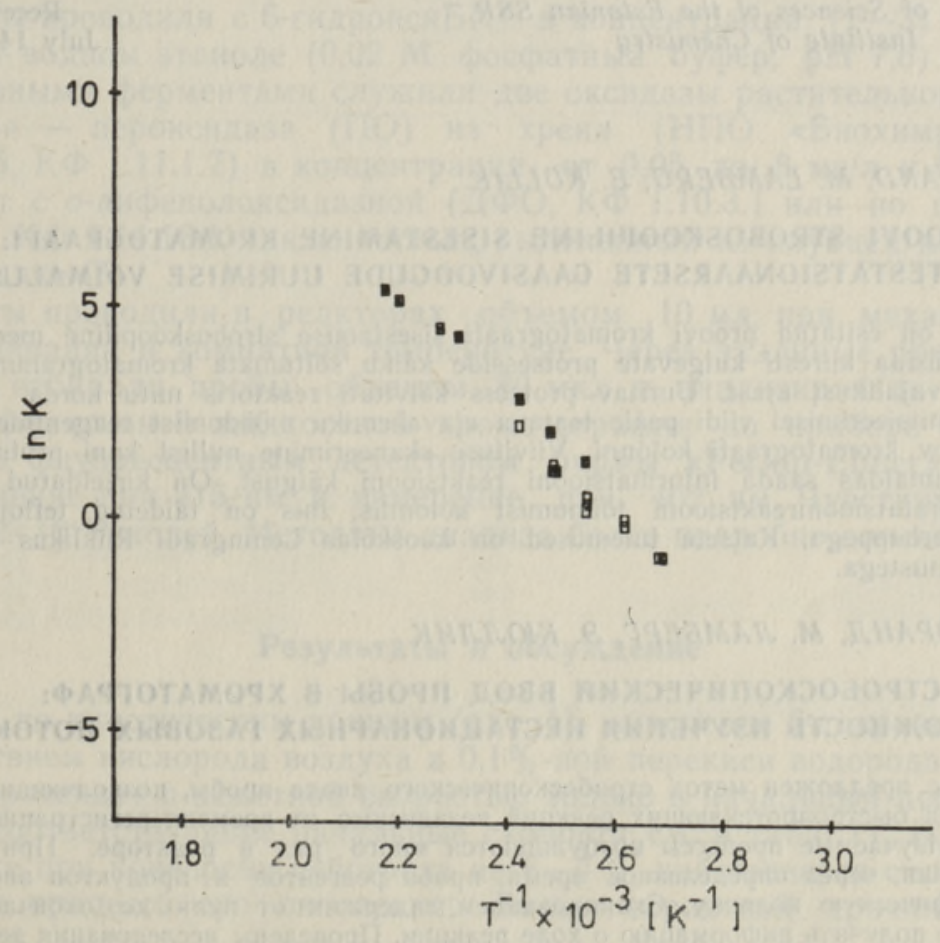

Fig. 3. Arrhenius plot for dehydrogenisation reaction products formation. Open squares LSU measurements, filled squares - present work, 
In LSU, the reagent was injected into the catalyst column by a microsyringe. However, because of the logarithmic dependence of the rate constant on the activation energy and pre-exponential factor a difference of $1.5 \%$ leads to a significant difference in the rate constants obtained in both experiments ( $2-3$ times).

It follows from the results that stroboscopic sampling can give reliable results in fast reaction rate measurements. The system described provides a reproducible (at the required degree) chemical process. Two important features of stroboscopic sampling become evident from the above discussion that are satisfied simultaneously:

1) time resolution of the nonstationary gas flow (theoretically up to $10 \mathrm{msec}$ );

2) chromatographic separation of the nonstationary flow components.

The authors are grateful to Assistant Professors B. V. Stolyarov and A. N. Marinichev (Leningrad State University) for presenting the problem of fast reaction measurements by chromatography, for their valuable discussions and for providing the catalyst.

\section{REFERENCES}

1. Кюллик Э., Кальюранд М. Компьютерная хроматография с многократным вводом пробы. Таллин, Препринт АН ЭССР, 1986.

2. Shushunova, A. F., Prokhorova, L. Y. Kinetic investigation of the thermal decomposition of organic peroxides by pulse chromatography. - J. Chromatogr., 1984, 283, 365-370.

3. Мариничев A. Н., Ноффе Б. В. Непрерывная газовая экстракция летучих продуктов жидкофазных реакций. - Докл. АН СССР, 1987, 292, 1181-1185.

4. Ноффе Б. В., Качанос Н. А., Коковина Л. А., Мариничев А. Н., Столяров Б. В. Изучение кинетики обратимых жидкофазных реакций, осложненных массообменом методом ГХИП. - In: Тез. докл. IX Всесоюз. конф. по газовой хроматографни. Куйбышев, 1987, 154-156.

Academy of Sciences of the Estonian SSR, Institute of Chemistry

Received July 14,1987

\section{KALJURAND, M. LAMBERG, E. KOLLIK}

\section{PROOVI STROBOSKOOPILINE SISESTAMINE KROMATOGRAAFI: MITTESTATSIONAARSETE GAASIVOOGUDE UURIMISE VOIMALUS}

Artiklis on esitatud proovi kromatograafi sisestamise stroboskoopiline meetod, mis lubab analüüsida kiiresti kulgevate protsesside käiku sõltumata kromatogrammi registreerimiseks vajalikust ajast. Uuritav protsess käivitati reaktoris mitu korda. Protsessi igakordsel initsieerimisel viidi peale teatava ajavahemiku möödumist reagentide ja produktide proov kromatograafi kolonni. Viivituse skaneerimine nullist kuni protsessi lôppemiseni võimaldas saada informatsiooni reaktsiooni käigust. On kirjeldatud isobutanooli dehüdratatsioonireaktsiooni toimumist kolonnis, mis on täidetud teflonkandjale kantud fosforhappega. Katsete tulemused on kooskōlas Leningradi Riiklikus Úlikoolis saadud tulemustega.

\section{М. КАЛЬЮРАНД, М. ЛАМБЕРГ, Э. КЮЛЛИК}

\section{СТРОБОСКОПИЧЕСКИИ ВВОД ПРОБЫ В ХРОМАТОГРАФ: ВОЗМОЖНОСТЬ ИЗУЧЕНИЯ НЕСТАЦИОНАРНЫХ ГАЗОВЫХ ПОТОКОВ}

В статье предложен метод стробоскопического ввода пробы, позволяющий анализировать ход быстропротекающих реакций независимо от времени регистрации хроматограммы. Изучаемые процессы возбуждаются много раз в реакторе. При каждом инициировании, через определенное время, проба реагентов и продуктов вводится в хроматографическую колонку. Сканированием задержки от нуля до окончания процесса можно получить информацию о ходе реакцин. Проведены исследования дегидратации изобутанола на колонке, наполненной фосфорной кислотой, нанесенной на тефлоновые шарики. Результаты опытов согласуются с результатами, полученными методом стоп-флоу в Ленинградском государственном университете, 